\title{
The meteorologically abnormal year of 2006 and natural disasters in the Philippines
}

1 National Institute of Geological Sciences, College of Science, University of the Philippines, Diliman, Quezon City, Philippines.
E-mail: gpyumul@dost.gov.ph; rwg@i-next.net
2 Philippine Atmospheric, Geophysical and Astronomical Services Administration, Department of Science and Technology, Quezon City, Philippines.

In the early part of 2006 the Philippines was hit by a La Niña event which brought floods, flashfloods and landslides. The most significant event was the February 2006 landslide that covered the whole community of Guinsaugon, in Southern Leyte, resulting in 154 deaths with 973 people still missing. Another rare event was the simultaneous presence of two tropical cyclones inside the Philippine Area of Responsibility (PAR) in AugustTropical Depression Bopha and Tropical Storm Saomai-that enhanced the southwest monsoon. With the strong winds and high waves associated with the southwest monsoon, an oil tanker, the M/T Solar 1, sank, resulting in the worst oil spill the country has ever suffered. Lastly, with a weak El Niño phenomenon forming in the Pacific Ocean and affecting the Philippines, a destructive typhoon, Xangsane, made a multi-landfall before hitting Metropolitan Manila. This was followed by the landfall of three supertyphoons-Cimaron, Chebi and Durian-during the last quarter of the year, bringing tremendous destruction of life and property. The occurrence of these weather events are attributed to climate variability the effects of which were exacerbated by a range of factors that include inappropriate land use.

\section{Introduction}

The Philippines is known to be a natural hazard- and disaster-prone country. Both endogenic (e.g. volcanological, seismological) and exogenic (e.g. mass wasting, tropical cyclones) hazards are present in the country. The country is an island arc bounded by two trench systems resulting in the subduction of oceanic crusts on both sides of the archipelago (Figure 1). Two apparent results of this activity are the generation of earthquakes (which can trigger tsunamis) and the formation of volcanoes (e.g. Yumul et al., 2003; Ramos et al., 2005). Several volcanic arc systems characterize the Philippines. Some of the active volcanoes that are being monitored at present are the Taal, Mayon and Bulusan volcanoes in Luzon, and the Kanlaon volcano in Negros Oriental (Fig-

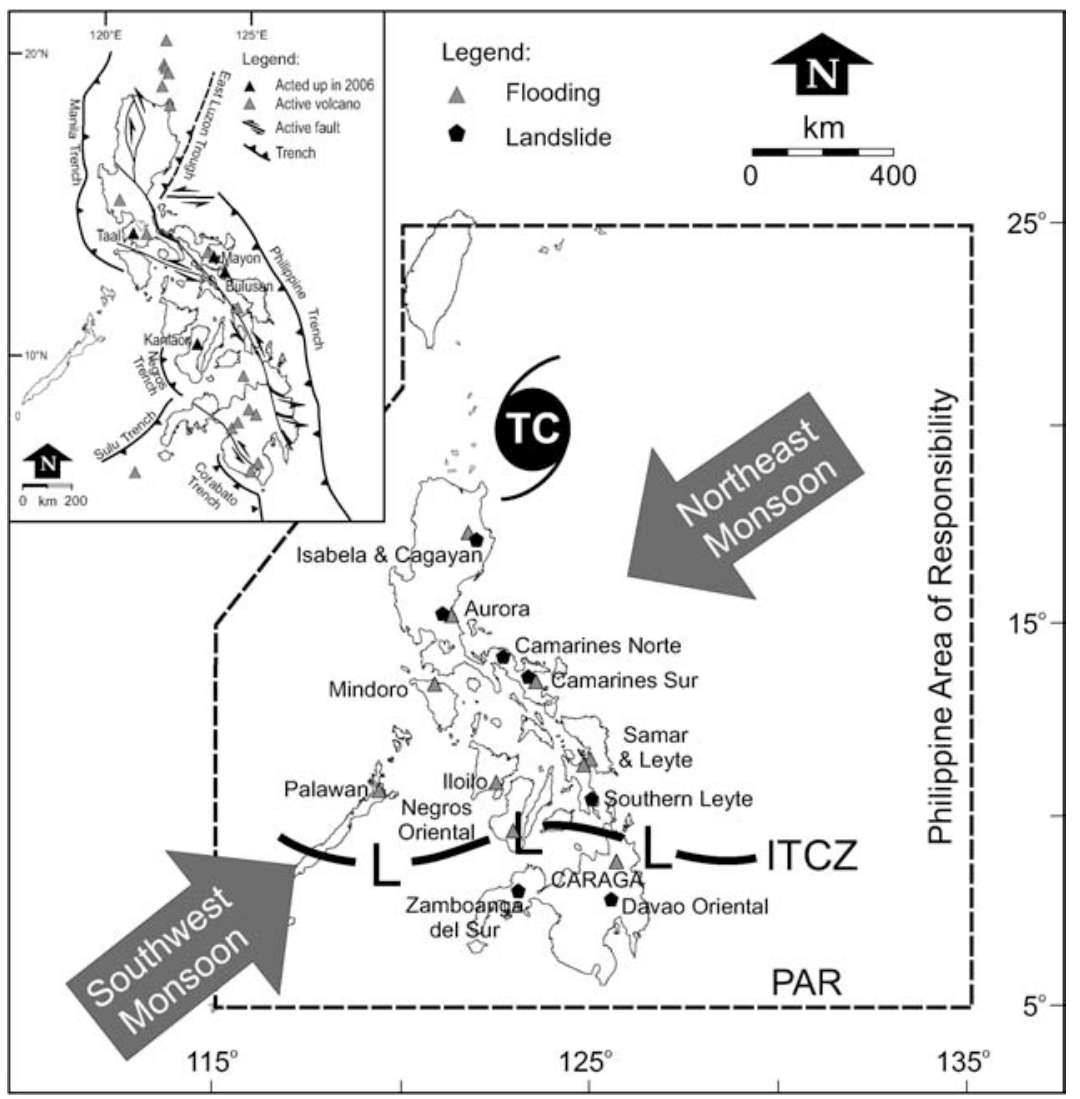

Figure 1 The country's natural hazard woes are compounded by major weather events that bring rains at different times of the year. These are the northeast monsoon (October-March), southwest monsoon (April-September), the intertropical convergence zone (ITCZ) and tropical cyclones (TC) (modified from DOST-PAGASA). The La Niña event which only began to develop in November 2005 led to long-duration floodings, landslides and village isolation, among others. Devastated areas were mostly along the eastern seaboard of the Philippines. (Inset) There are twenty two active volcanoes in the Philippines and four of these showed signs of activity in 2006 (i.e. Mayon, Bulusan, Taal and Kanlaon). Being surrounded by trenches, the Philippines is also a
seismologically-active region. PAR $=$ Philippine Area of Responsibility.

ure 1). Aside from the above-mentioned endogenic hazards, the country is vulnerable to several tropical cyclone-related exogenic hazards. The PAR (Figure 1) is transected by an average of 19 tropical cyclones annually, of which 9 make landfall. Some of the hazards related to this include strong winds, mass wasting (e.g. landslides, mudslides, lahar deposit remobilization), tidal waves, storm surges and tornadoes, to name a few, similar to what is observed in other countries (e.g. Emanuel, 2003, 2005; Lee et al., 2006). Aside from tropical cyclones, the other weather events that affect the country include the inter-tropical convergence zone, the northeast monsoon prevalent during the months of October to March and the south- 
west monsoon during the period April to September every year (Figure 1) (Kintanar, 1984). The year 2006 was a meteorologically abnormal year for the Philippines. The presence of La Niña in the early part of the year, the enhancement of the Southwest Monsoon due to the interaction of two tropical cyclones inside the PAR and the initiation of an El Niño characterized by super-typhoons hitting the Luzon-Visayas region are some of the events. This paper will briefly characterize each major event, the hazards that were generated and the corresponding disasters that were initiated. It is hoped that the lessons learned from each event can add to our existing knowledge on how to handle similar future occurrences, and, in the process, mitigate the resulting disastrous effects.

\section{6: A meteorologically abnormal year}

In 2006, the Philippines was successively battered by a series of weather-related disasters which include the following: a) La Niña in the first quarter of the year that resulted in a major landslide; b) the enhanced Southwest Monsoon that resulted in the worst oil spillrelated coastal degradation in Central Philippines; c) Typhoon Xangsane (local name Milenyo) that hit Metropolitan Manila causing enormous destruction; and d) El Niño in the last quarter of the year characterized by a series of super-typhoons.

\section{La Niña}

The first quarter of the year 2006 was characterized by a La Niña event that started during the latter part of 2005 and ended in May 2006. This event was considered atypical because it started later than usual. La Niña events often start during the months of June to August, and usually mature by December to January. How-
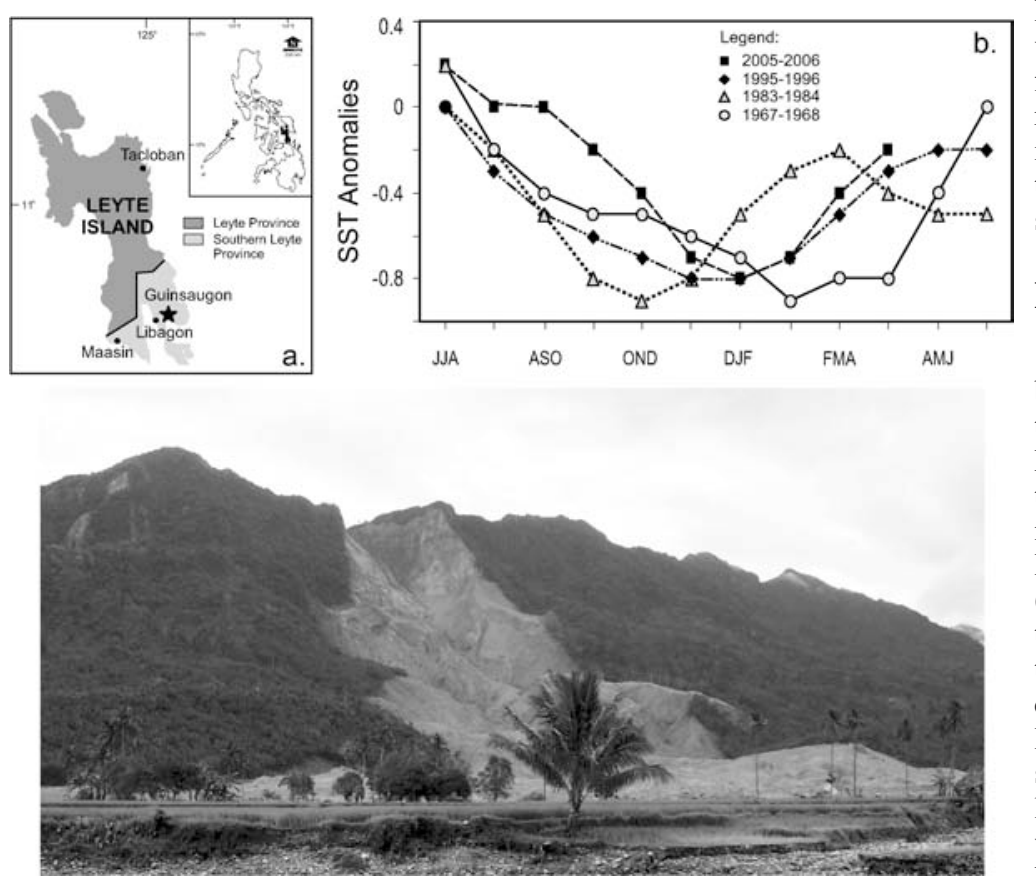

Figure 2 Continuous rains for the first twelve days of February 2006 characterized the precursor of the February 17, 2006 Guinsaugon, Southern Leyte landslide. Inset a shows the location of Leyte Island (light gray-shaded area). Inset b shows the comparison of seasonal sea surface temperature anomalies (Nino 3.4 region) of selected La Niña events. The other La Niña events (1995-1996; 1983-1984; 1967-1968) are shown for comparison with the 2005-2006 La Niña (Data source: National Climatic Data Center, National Oceanic and Atmospheric Administration). See text for details. SST=sea-surface temperature. Legend: JJA=June to August; $A S O=A$ ugust to October; OND=October to December; $D J F=D e c e m b e r$ to February; FMA=February to April; AMJ=April to June. ever, the 2005-2006 La Niña event only started to develop in November (Figure 2). The development of the La Niña event became conducive to the formation of locally rain-producing weather systems such as a Low Pressure Area (LPA) and synoptically frontal system that resulted in heavy rain. As a consequence, floods, flash floods, landslides, dike embankment destruction and village isolation were common during the first quarter of the year (Figure 1). The eastern seaboard of the Philippines was very susceptible to the consequences of the strong rains and winds associated with a rain-producing weather system that accompanied the La Niña event.

The most destructive event that resulted from this was the landslide that buried the whole village of Guinsaugon, St. Bernard in Southern Leyte (Figures 1, 2) (e.g. Catane et al., 2006; Evans et al., 2007). The rain that fell in Maasin, Leyte, approximately $35 \mathrm{~km}$ southwest of Guinsaugon, during the period February 1-20, 2006 measured $623 \mathrm{~mm}-495 \%$ more compared to the 30 -year climatological value of $137 \mathrm{~mm}$ covering the period 1970-2000. In the Otikon station in Libagon, roughly $5 \mathrm{~km}$ west of Guinsaugon, rainfall for the same period was measured at $787 \mathrm{~mm}$ (Figure 2a). This was $271 \%$ of the $290 \mathrm{~mm}$ normal rainfall. A combination of factors had interacted that led to this massive landslide which claimed 154 lives with 973 persons still missing (and presumed dead) (InterAgency Committee on the Guinsaugon, Southern Leyte Landslide, 2006). The landslide occurred along the left-lateral Philippine Fault Zone that traverses the island of Leyte. The rocks in the area are generally weathered and clayey in some portions. Although two low-magnitude earthquakes were reported before the event and the avalanche occurred four days after the peak rainfall period (February $8-12,2006)$, the Guinsaugon landslide is believed to have been raininduced (Yumul et al., 2006). Being located in a valley, the microclimate of the area was totally different from what was being recorded by the Department of Science and Technology Philippine Atmospheric, Geophysical and Astronomical Services Administration (DOST-PAGASA) synoptic and rainfall stations outside of the disaster-stricken area during the rescue and relief operations. To address this concern, two meteorologists were assigned by the national government to the area to help in monitoring the weather and microclimate situation during that period.

\section{Enhanced Southwest Monsoon}

The month of August in the Philippines is characterized by the Southwest Monsoon (Figure 1). Rains associated with the Southwest Monsoon in August dominantly affect the Luzon-Visayas area. During the period August 5-8, 2006, a tropical depression and later tropical storm Bopha (local name Inday) developed from a low pressure area within the PAR. This was followed by the arrival of typhoon Saomai (local name Juan). Thus, in August 2006 there were two tropical cyclones inside the PAR (Figure 3). The last time this phenomenon was observed was in 1990. With the presence of two tropical cyclones and with Saomai stronger than Bopha it was the former that enhanced the Southwest Monsoon. With this configuration, the Southwest Monsoon followed a trajectory that resulted in its bringing a lot of rain and wind to the Visayas and Mindanao region, instead of the Luzon-Visayas area (Figure 3). The strong rains caused a lot of flash floods, long-duration floods and landslides in the Vasayas and Mindanao region. The strong winds resulted in very rough seas, with tidal waves inundating several coastal areas. The two tropical cyclones eventually combined and hit China, leading to several deaths. Tropical cyclone Bopha (Juan; the name assumed by the tropical cyclone after Saomai and Bopha combined) was reported to be the strongest to hit China in 50 years (Duan, 2006). Strong winds associated with the enhanced Southwest Monsoon and available wave model information were the bases for the August 10, 2006 gale warning issued by the DOST-PAGASA, the official 


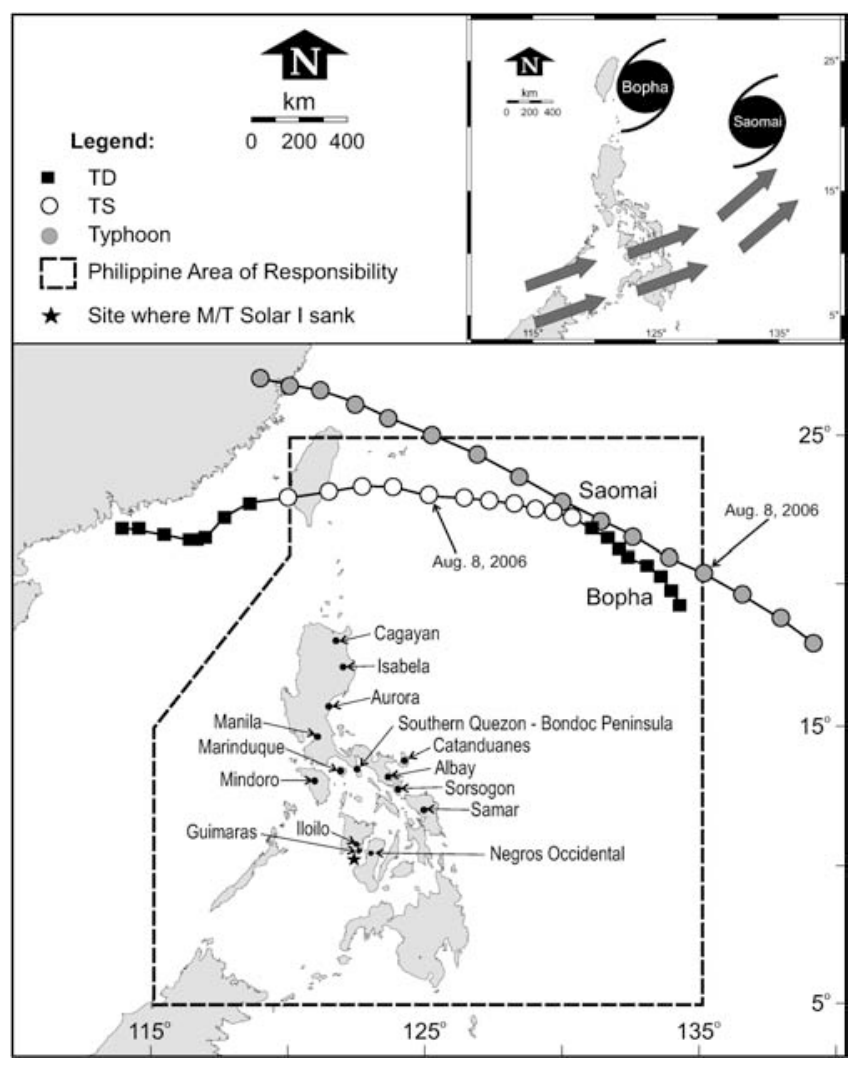

Figure 3 On August 8, 2006, both tropical cyclones Bopha and Saomai were inside the Philippine Area of Responsibility. (Inset) With Saomai being stronger than Bopha, it enhanced the Southwest Monsoon and caused the monsoon to follow a trajectory (represented by arrows) that brought rains and winds in the Visayas and Mindanao areas. Strong winds and reported high waves contributed to the sinking of the M/T Solar 1, an oilcarrying tanker ship off the southern coast of Guimaras Island (black star). Some coastal towns in Guimaras, Iloilo and Negros Occidental were affected by the oil spill. TD=tropical depression; TS=tropical storm.

Philippines national government meteorological-hydrological agency. Small and large craft in Mindoro and in the western and eastern seaboards of Visayas and Mindanao were alerted against moderate- to high waves ( 3 to $6 \mathrm{~m}$ high). Unfortunately, an oil tanker, the M/T Solar 1, sank in rough seas. In the course of its sinking, it reportedly released a substantial amount of oil, causing the worst oil spill the Philippines had ever suffered (Figure 3). The oil spill affected the coastal towns of Guimaras, Iloilo and Negros Occidental. The island province of Guimaras was the worst affected by the M/T Solar 1 oil spill, with adverse effects on its marine sanctuary, marine resources and tourism.

\section{Typhoon Xangsane}

Tropical cyclone Xangsane (local name Milenyo) entered the PAR as a low-pressure area. It was then upgraded to a tropical depression (wind speed: $55 \mathrm{~km}$ per hour), through a tropical storm (wind speed: $65 \mathrm{kph}$ ) and ultimately to a typhoon (wind speed: 130 kph) category (Figure 4a). Tropical cyclone Xangsane moved in a straight and multi-landfall fashion. The first landfall was in Samar, followed by Sorsogon and ultimately Southern Quezon-Bondoc Peninsula before crossing Metropolitan Manila (Figures 3 and 4a). After hitting Samar, it crossed a part of the Philippine Sea thus regaining strength before hitting Sorsogon. Tropical cyclone Xangsane maintained its strength after crossing Sorsogon, passing over the Ragay Gulf (which provided the much-needed moisture for

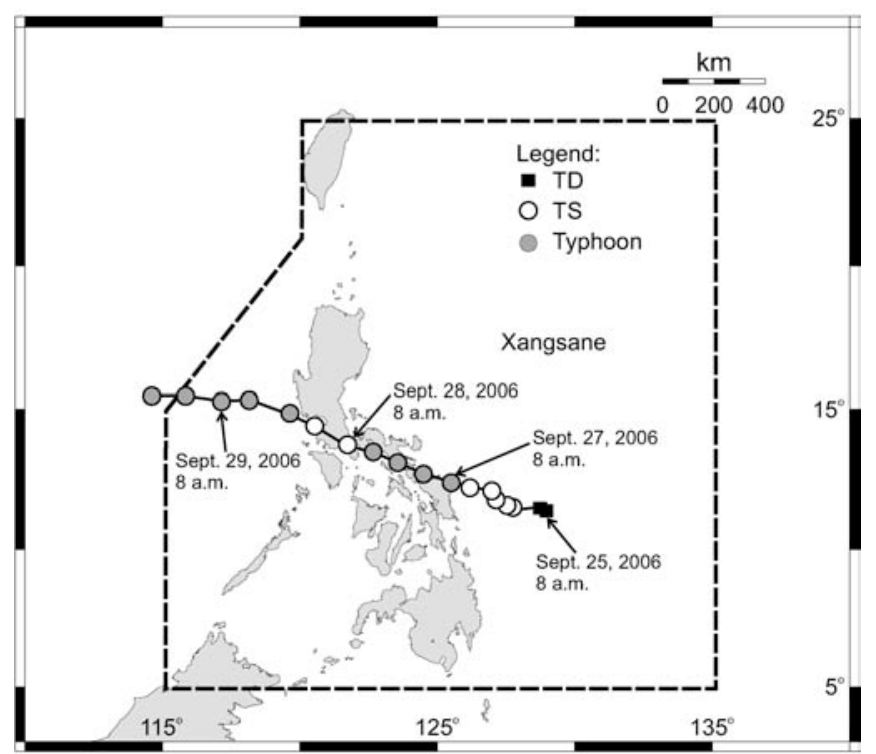

Figure 4a Tropical cyclone Xangsane started as a low pressure area east of Samar but quickly intensified into a typhoon. As this tropical cyclone moved landward, it left behind a trail of destruction amounting to $\sim$ US\$130M.

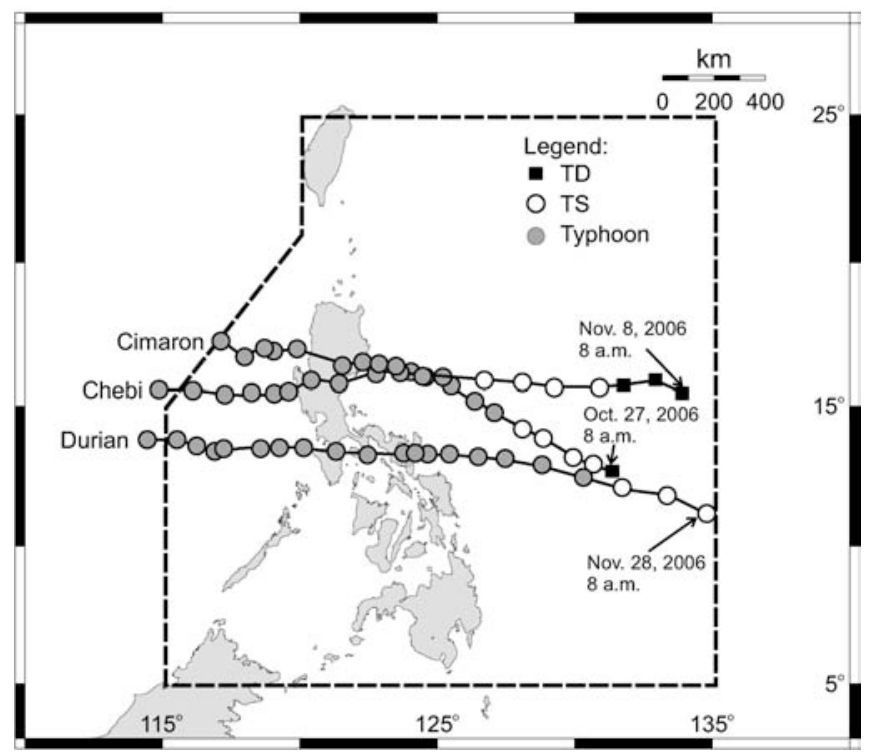

Figure $4 b$ The latter part of 2006 saw three supertyphoons (i.e. sustained winds in excess of $185 \mathrm{kph}$ ) hitting the Philippines one after the other. Cimaron and Chebi battered the northeastern seaboard of the country (i.e. Aurora and Isabela) whereas Durian devastated the Catanduanes-Albay region. See Figure 3 for area locations.

its strength), before hitting Southern Quezon-Bondoc Peninsula area. From Samar through Sorsogon and Southern Quezon-Bondoc Peninsula all the way to Metropolitan Manila and vicinity, tropical cyclone Xangsane left a massive trail of destruction. The damage it caused (worth approximately US\$130 million) was greater than the combined damage of the Guinsaugon landslide and the M/T Solar 1 oil spill. Landslides, floods, destruction of dike embankments and the toppling of electricity pylons resulting in power outages and deaths were some of the significant damages.

\section{EI Niño and supertyphoons}

For the first time in the history of the Philippines three consecutive supertyphoons hit the country within a 30 -day period. These 
a.

Number of Extreme Typhoons in the PAR (with maximum sustained winds of $150 \mathrm{kph}$ and above) (Period: 1971-2007)

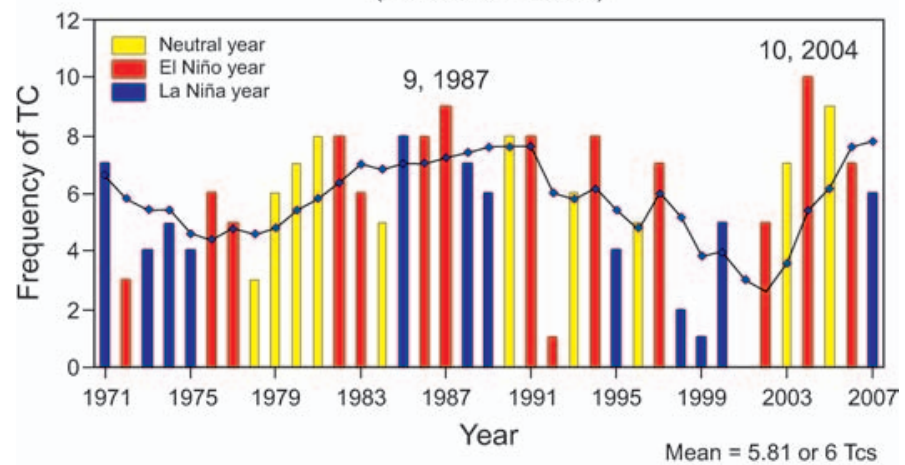

b.

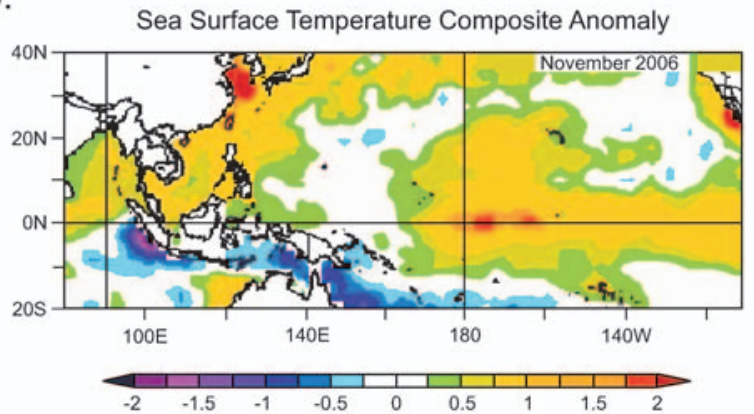

Figure 5 a. The annual frequency distribution of stronger typhoons with maximum sustained winds of $150 \mathrm{kph}$ and above within the PAR, from the period 1971 to 2007 , relative to neutral, warm and cold ENSO events (data from the Philippine Atmospheric, Geophysical and Astronomical Services Administration). No tropical cyclones with maximum sustained winds of $150 \mathrm{kph}$ and above entered the PAR in 2001.

b. The November 2006 sea surface temperature (SST) anomaly showing warmer than normal SSTs over the central and eastern equatorial Pacific Ocean during an El Niño event. The SST over the Philippines especially in the northern part (yellow color) was unusually warm during this El Niño event (data from the National Centers for Environmental Prediction/National Center for Atmospheric Research (NCEP/NCAR) Reanalysis of the National Oceanic and Atmospheric Administration).

were Cimaron (local name Paeng), Chebi (local name Queenie) and Durian (local name Reming). The maximum sustained winds of these supertyphoons registered higher than $185 \mathrm{kph}$, during which a Public Storm Warning Signal four (4) was hoisted in affected areas, the highest category in the Philippine public storm warning signal system. Supertyphoon Cimaron made landfall on 29 October 2006 in Southern Isabela and exited on 30 October in La Union; supertyphoon Chebi made landfall on 11 November in Aurora, and exited on the same day in Pangasinan; supertyphoon Durian made its initial landfall in Catanduanes on 30 November, followed by Albay, Southern Quezon-Bondoc Peninsula and Marinduque, and ultimately exited near Mindoro on December 1, 2006 (Figure 4b). Supertyphoons Cimaron and Chebi battered the northeastern seaboard, specifically the provinces of Aurora and Isabela, resulting in the destruction of many coastal communities. Supertyphoon Durian saturated the lahar deposits on the slopes of the Mayon volcano resulting in their remobilization and deposition on communities near the base of the volcano. More than 600 people died in this disaster. While the records show that several strong typhoons occurred during El Niño years, notably in 1987 and 2004 (Figure 5a), what was not normal was the occurrence of the three supertyphoons in an on-going El Niño event in the Philippines. El Niño events in the country are usually characterized by drought.

\section{Discussion}

\section{EI Niño Southern Oscillation phenomenon}

El Niño and La Niña are components of a climate cycle referred to as El Niño Southern Oscillation (ENSO). Generally, these phenomena tend to develop during the period April-June and reach their maximum strength during December-February. In the Philippines, seasonal rainfall is known to be modulated by the ENSO phenomenon, with ENSO warm (cold) events frequently contributing to drought (excessive rainfall) in many areas (Lyon et al., 2006). The 2005-2006 La Niña event, as stated earlier, developed between November-December 2005. Observations showed that in the development stage the sea-surface temperature (SST) had become anomalously cool in the central and eastern areas of the equatorial Pacific Ocean (National Climatic Data Center, 2006). Cooler-than-normal SSTs continued to be observed in the central and eastern equatorial Pacific Ocean during the first four months of 2006, with the coldest SST anomalies measured in January in the central equatorial Pacific. Various computer models produced by international climate centers predicted that conditions should have returned to a neutral state by mid-2006. However, observations showed that near-normal conditions returned as early as in April 2006. Experts agree that the development of tropical Pacific Ocean and atmospheric anomalous conditions at that time of the year was highly unusual (World Meteorological Organization, 2006), leading to some additional uncertainty about the rainfall patterns associated with this event. The impact of this La Niña event on the local weather and climate conditions was characterized by occurrences of heavy rain, despite the absence of tropical cyclone activity in the PAR. This resulted in massive flooding and mass wasting in Luzon, Visayas and Mindanao. By the beginning of September 2006, rapid warming in the upper ocean along the equatorial zone in the Pacific basin was the first sign that an ENSO warm event (El Niño) had begun to develop (National Climatic Data Center, 2006). Observations of the equatorial Pacific showed that continuous warming persisted towards the end of 2006. By the end of November 2006, SSTs had become significantly above normal in the central and eastern areas. In addition, during this period, other indicators used to monitor El Niño, such as the Southern Oscillation Index (SOI), showed consistent readings indicative of the occurrence of a moderate El Niño event. The recent warm phase of the ENSO episode was predicted by international climate centers as persisting until the early part of 2007. Surprisingly, the effects of this El Niño on the local climate, particularly on the local rainfall pattern, did not match the anticipated conditions. Based on previous studies (e.g. Jose, 1997), the El Niño events in the country are characterized by weak monsoon activity and fewer tropical cyclones during the later part of the year. But in the last few months of 2006 three successive strong typhoons crossed the Philippine landmass, one of which (Typhoon Reming) caused significant loss of lives and massive destruction to property. Rainfall analyses for the November-December 2006 period showed that most parts of the country received more rain than usual, in contrast to the expected less rain during an El Niño event. It is likely that the development of strong land-falling typhoons in the last few months of 2006 despite the occurrence of an El Niño phenomenon was due to relatively warm waters in the northern and central portion of the Philippines (Figure 5b). The prevalence of warmer SST within Philippine waters during an El Niño event contradicts previous studies (e.g. Jose, 1997). The interaction of oceanic and atmospheric conditions could have led to the unexpected occurrence of more rainfall in most parts of the country during an El Niño event. Other local factors could have contributed to this abnormal weather pattern, such as the Madden Julian Oscillation (MJO) and the Indian Ocean Dipole (IOD). How the local-scale MJO modified the synoptic circulation and what the role of IOD in the abnormally wet 2006 El Niño was are topics of further detailed scientific investigation. On the issue of whether the behavior of recent El Niño and La Niña events and its associated 
impacts could be directly attributed to climate change or other factors is still uncertain (e.g. Kumar et al., 2006; van Aalst, 2006). Although the recent Intergovernmental Panel on Climate Change (2007a, b) reports show increased evidence for global warming, the direct correlation with ENSO on a per region basis, among others, is still not that fully constrained (e.g. Meehl et al., 2003, 2004).

\section{Typhoon occurrences and government's response}

There have been some contentions that with the observed climate change there has been a global trend of increased duration, intensity and frequency of tropical cyclones (e.g. Goldenberg et al., 2001; Emanuel, 2005; 2006). However, other scientists have pointed out that there are still a lot of uncertainties to readily conclude that, with global warming, these factors related to tropical cyclones increase (e.g. Trenberth, 2005; Webster et al., 2005). Although there has been a reported trend of increasing tropical cyclones in the Atlantic, this has not been readily observed in the Northwest Pacific (Wu et al., 2006). It appears that regional variability is more the norm than the exception. Furthermore, to attribute everything to climate change and other related anthropogenic causes may not necessarily be correct (Klotzbach, 2006). Studies show that there are a lot of recorded events that cannot be differentiated from those occurring related to natural multi-decadal oscillation. The global warming signals regarding tropical cyclones are small enough to be masked at present by natural variability signatures. The 2006 weather and climate variabilities noted in the Philippines may either be a local phenomenon or a response to a larger yet unclear regional meteorological situation. The available information nonetheless show that the 30-year climatological data of the Philippines (1974-2004 in DOST-PAGASA) is not consistent with an increase in tropical cyclone frequency, duration and intensity. This is something that needs to be addressed in future studies.

Inspite of these uncertainties, the Philippine government has taken action to address weather- and climate-related concerns. As pointed out, the geological and meteorological setting of the Philippines makes it prone to various natural hazards and disasters. This is compounded by inappropriate land use in some parts of the country, making communities more vulnerable to natural-hazard-related risks. People also tend to ignore government forecasts and warnings, in some instances, leading to disastrous results. In order to ensure that the relevant agencies are able to respond quickly and effectively to disasters resulting from typhoons, floods, earthquakes and other related natural hazards, the Philippine National Disaster Coordinating Council (NDCC) is implementing a program that aims to minimize if not totally prevent disasters through its Four-Point Action Plan: 1. Upgrading the forecasting capability of the government's meteorological-hydrological and volcanological-seismological frontline agencies; 2 . Intensive information and education campaign which also involves the Catholic Church; 3 . Enhancement of the capacity of the local chief executives in disaster management; and 4. Engagement with the private sector in the rehabilitation efforts in affected communities. Various national government agencies, as members of the NDCC, provide rapid responses whenever a disaster occurs. As long-term precautions, provision of multi-hazard and risk maps and appropriate land-use plans are provided by the concerned agencies to local government units for identifying resettlement areas, thus moving communities out of harm's way. The local populace are engaged intensively to ensure that, as stakeholders, they join local disaster-mitigation efforts. The Philippines, in spite of the country's limited resources, has been able to effectively minimize the disastrous effects brought about by the various extreme natural events that affect the country. As a result, a more resilient people has sprung up effectively addressing the vulnerabilities of their communities.

\section{Conclusions}

The Philippines experienced a number of extreme weather and climate events (e.g. ENSO, tropical cyclones) in 2006 that affected the country in terms of loss of life and destruction of property. Available information suggests that local natural variability may more readily explain the observations made in relation to ENSO and tropical cyclones. The so-called global trend in particular in increase in tropical cyclone intensity, duration and frequency is not readily noted in the Philippines. Nevertheless, the Philippine government has proactively acted on its disaster management program, resulting in better public capacity to handle hazards.

\section{Acknowledgments}

The support extended to us by the Department of Science and Technology, UP-National Institute of Geological Sciences, DOST-Philippine Atmospheric, Geophysical and Astronomical Services Administration, DOST-Philippine Council for Industry and Energy Research and Development and the National Disaster Coordinating Council is acknowledged with gratitude. We would also like to thank the officials and personnel of the different local government units, regional, provincial and municipal disaster coordinating councils that we have worked with. The men and women of DOSTPAGASA unselfishly shared their data and knowledge with us. Comments by an anonymous reviewer, R.A.L. Flores and Dr. L.A. Amadore are highly appreciated. This is UP-NIGS Contribution No. 2008-05.

\section{References}

Catane, S.G., Cabria, H.B., Tomarong, C.P., Saturay, R.M.J., Zarco, M.A.H and Pioquinto, W.C., 2006, Catastrophic rockslide-debris avalanche at St. Bernard, Southern Leyte, Philippines: Landslides, DOI 10.1007/s10346006-0050-3.

Duan, Y.H., 2006, Why were the impacts of Bilis and Saomai so severe? WMO Special Feature. www.wmo.ch/web/Press/Duan.pdf

Emanuel, K., 2003, Tropical cyclones: Annual Review of Earth and Planetary Sciences, v. 31, pp. 75-104.

Emanuel, K., 2005, Increasing destructiveness of tropical cyclones over the past 30 years: Nature, v. 436, pp. 686-688.

Emanuel, K., 2006, Hurricanes: Tempests in a greenhouse: Physics Today, v. 59, pp. 74-75.

Evans, S.G., Guthrie, R.H., Roberts, N.J. and Bishop, N.F., 2007, The disastrous 17 February 2006 rockslide-debris avalanche on Leyte Island, Philippines: a catastrophic landslide in tropical mountain terrain: Natural Hazards Earth System Science, v. 7, pp. 89-101.

Goldenberg, S.B., Landsea, C.W., Mestas-Nuñez, A.M. and Gray, W.M., 2001, The recent increase in Atlantic hurricane activity: Causes and implications: Science, v. 293, pp. 474-479.

Inter-Agency Committee on the Guinsaugon, Southern Leyte Landslide, 2006, The 17 February 2006 Barangay Guinsaugon, Southern Leyte Landslide: Government of the Philippines, 18pp.

Intergovernmental Panel on Climate Change Working Group II Fourth Assessment Report, 2007a, Climate Change 2007: The Physical Science Basis: Summary for Policymakes, 18 pp.

Intergovernmental Panel on Climate Change Working Group II Fourth Assessment Report, 2007b, Climate Change 2007: Climate Change Impacts, Adaptation and Vulnerability: Summary for Policymakes, 23 pp.

Jose, A.M., 1997, A Study on Potential Indicators/Indices of Tropical Cyclone Variability/Changes in the Philippine Vicinity (1948-1997): Philippine Atmospheric, Geophysical and Astronomical Services Administration, Quezon City, Philippines.

Kintanar, R.L., 1984, Climate of the Philippines: Philippine Atmospheric, Geophysical and Astronomical Services Administration, Quezon City, Philippines, 38 pp. 
Klotzbach, P.J., 2006, Trends in global tropical cyclone activity over the past twenty years (1986-2005): Geophysical Research Letters, v. 33, L10805. doi:10,1029/2006 GL025881.

Kumar, K.K., Rajagopalan, B., Hoerling, M., Bates, G. and Cane, M., 2006, Unravelling the mystery of Indian monsoon failure during El Niño: Science, v. 314, pp. 115-119.

Lee, C.-S., Huang, L.-R., Shen, H.-S. and Wang, S.-T., 2006, A climatology model for forecasting typhoon rainfall in Taiwan: Natural Hazards, v. 37, pp. 87-105.

Lyon, B., Cristi, H., Verceles, E.R., Hilario, F.D. and Abastillas, R., 2006, Seasonal reversal of the ENSO rainfall signal in the Philippines: Geophysical Research Letters, v. 33, L24710. doi:10.1029/2006GL028182.

Mann, M.E. and Emanuel, K.A., 2006, Atlantic hurricane trends linked to climate change: EOS, v. 87, pp. 233-244.

Meehl, G.A., Washington, W.M., Wigley, T.M.L., Arblaster, J.M. and Dai, A., 2003, Solar and greenhouse gas forcing and climate response in the twentieth century: Journal of Climate, v. 16, pp. 426-444.

Meehl, G.A., Washington, W.M., Ammann, C.M., Arblaster, J.M., Wigley, T.M.L. and Tebaldi, C., 2004, Combinations of natural and anthropogenic forcings in twentieth-century climate: Journal of Climate, v. 17, pp. 3721-3727.

National Climatic Data Center, 2006, Climate of 2005: El Niño/Southern Oscillation (ENSO). http://1wf.ncdc.noaa.gov/oa/climate/research/2005/ enso-monitoring.html

National Climatic Data Center, National Oceanic and Atmospheric Administration http://www.ncdc.noaa.gov/oa/ncdc.html

Ramos, N.T., Dimalanta, C.B., Besana, G.M., Tamayo, R.A.J., Yumul G.P.Jr. and Maglambayan, V.B., 2005, Seismotectonic reactions to the arc-continent convergence in Central Philippines: Resource Geology, v. 55, pp. 199-206.

Trenberth, K., 2005, Uncertainty in hurricanes and global warming: Science, v. 308, pp. 1753-1754.

Van Aalst, M.K., 2006. The impacts of climate change on the risk of natural disasters: Disasters, v. 30, pp. 5-18.

Webster, P.J., Holland, G.J., Curry, J.A. and Chang, H.R., 2005, Changes in tropical cyclone number, duration, and intensity in a warming environment: Science, v. 309, pp. 1844-1846.

World Meteorological Organization, 2006, El Niño/La Niña update - March 3, 2006, Switzerland.

Wu, M.-C., Yeung, K.-H. and Chang, W.-L., 2006, Trends in Western North Pacific tropical cyclone intensity: EOS, v. 87, pp. 537-538.

Yumul, G.P.Jr., Dimalanta, C.B., Tamayo, R.A.Jr. and Maury, R.C., 2003, Collision, subduction and accretion events in the Philippines: A synthesis: Island Arc, v. 12, pp. 77-91.

Yumul, G.P.Jr., Cruz, N.A., Dimalanta, C.B., Servando, N.T. and Nilo, P.D., 2006, Air-ocean interactions, resulting multi-hazard and why 2006 is an unusually meteorologically-abnormal year: Abstracts of Geocon 2006, Quezon City, Philippines, p 17.
Graciano Yumul Jr. is Professor of Geology at the National Institute of Geological Sciences, University of the Philippines. He obtained his D.Sc. from the University of Tokyo in 1990. His scientific interests include tectonics, igneous petrology and geochemistry. His recent interest in meteorological phenomena is due to his supervision of the Philippine Atmospheric, Geophysical and Astronomical Services Administration, Department of Science and Technology since 2005. This is part of his duties as Undersecretary (Deputy Minister) for Research and Development of the Department of Science and Technology which he is concurrently serving on a secondment basis.

Nathaniel Servando is currently Deputy Director for Research and Development of the Philippine Atmospheric, Geophysical and Astronomical Services Administration, Department of Science and Technology. His Ph.D. in Meteorology obtained in 1999 at the University of the Philippines, dealt with the behavior of tropical cyclones in the Western North Pacific. He studied and obtained his Master's degree in Marine Meteorology in Japan.

Nathaniel Cruz is presently Chief of the Weather Branch of the Philippine Atmospheric, Geophysical and Astronomical Services Administration, Department of Science and Technology. He is finishing his Ph.D. studies in Meteorology at the University of the Philippines. His interests include tropical cyclone and seasonal rainfall forecasting, El Niño and Southern Oscillation (ENSO) and understanding climate change impacts and adaptation in the Philippines. He is currently working on the analysis of rainfall patterns in the Philippines associated with tropical cyclone passage.
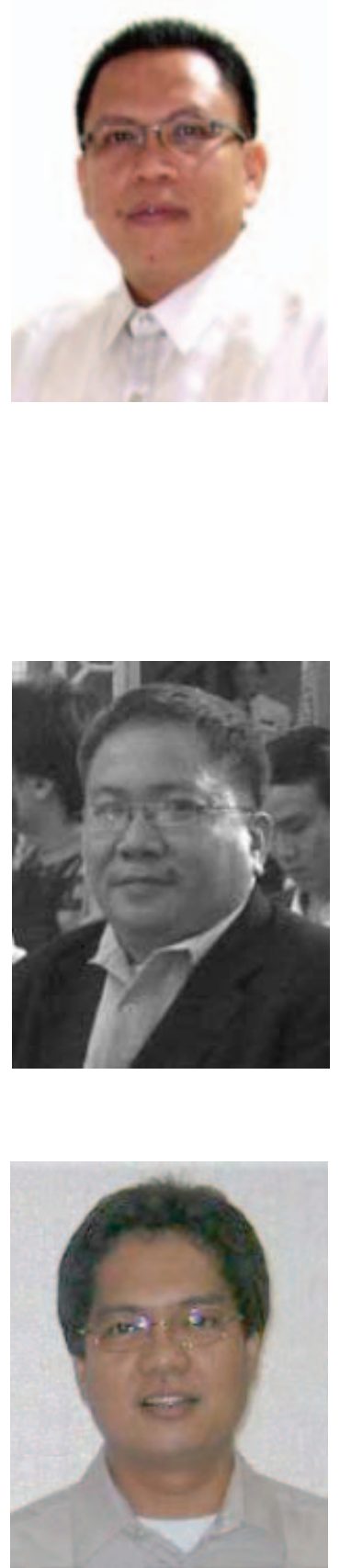